\title{
KONSEP PENDIDIKAN MUATAN LOKAL KECAKAPAN HIDUP BERBASIS PERTANIAN MELALUI KEBUN SAYUR SEKOLAH
}

\author{
Kuntoro Boga Andri \\ Balai Pengkajian Teknologi Pertanian (BPTP) Jawa Timur \\ Jl. Raya Karangploso Km 4, Kotak Pos 188 Malang Jawa Timur \\ Email: kuntoro@litbang.deptan.go.id
}

\begin{abstract}
ABSTRAK
Implementasi Muatan Lokal (Mulok) kecakapan hidup (lifeskill) dalam pembelajaran di sekolah sangat penting untuk menciptakan sumber daya manusia yang bermutu guna menjawab tantangan dimasa yang akan datang. Fakta menunjukkan tingkat konsumsi sayur penduduk Indonesia masih di bawah standar kecukupan dari yang direkomendasikan oleh Organisasi Kesehatan Dunia (WHO yaitu minimal sebesar 200g/kapita/hari. Sebagai perbandingan, tingkat konsumsi sayur di Thailand ialah $300 \mathrm{~kg} / \mathrm{kapita} /$ tahun. Negara tetangga yang tingkat konsumsi lebih tinggi dari Indonesia ialah Singapura, yang mengkonsumsi $120 \mathrm{~kg} / \mathrm{kapita} / \mathrm{tahun}$, kemudian Cina, mengkonsumsi $270 \mathrm{~kg} / \mathrm{kapita} / \mathrm{tahun}$, dan Kamboja yang mengkonsumsi $109 \mathrm{~kg} / \mathrm{kapita} / \mathrm{tahun}$. Selain itu konsumsi sayuran perlu ditingkatkan untuk mengurangi ketergantungan terhadap beras. Pengkajian penerapan kurikulum kecakapan hidup ini dilakukan dalam rangka mempromosikan peningkatan konsumsi sayur bagi siswa melalui model kebun sayur sekolah. Kebun sayuran sekolah dalam kegiatan ini juga dirancang untuk meningkatkan ketersediaan sayuran bagi konsumsi keluarga. Kebun diatur sedemikian rupa sehingga sayuran dapat dipanen hampir setiap hari dan dirancang menggunakan luas lahan yang kecil karena kebanyakan keluarga di Indonesia tidak memiliki halaman yang luas. Siswa terlibat dalam pemeliharaan tanaman sayuran sebagai latihan bercocok tanam sayur. Setiap panen sayuran direkap dan kandungan gizinya dihitung. Kedepan, perlu penerapan Standar Operasional Presedur (SOP) pelaksanaan kegiatan ini agar dapat berhasil dan mencapai tujuan dari pelaksanaan kurikulum ini.
\end{abstract}

Kata kunci : muatan lokal, kurikulum kecakapan hidup, diversifikasi konsumsi, kebun sayur sekolah

\section{EDUCATIONAL CONEPT OF LOCAL CONTENT LIFE SKILLS BASED ON AGRICULTRE THROUGH SCHOOL VEGETABLE GARDEN}

\begin{abstract}
Local Content (Mulok) Life skills implementation in learning process in the school is very important to built the high quality of human resources in order to meet future challange. The level of vegetables consumption of Indonesian population fact showed it is below the adequacy standard recommended by the World Health Organization (WHO) ie a minimum of $200 \mathrm{~g} /$ capita / day. In comparison, the level of vegetables consumption in Thailand is $300 \mathrm{~kg} /$ capita / year. The neighboring countries that higher vegetables consumption comparing Indonesia is Singapore, which consumes $120 \mathrm{~kg}$ / capita / year, then China, consuming $270 \mathrm{~kg} /$ capita / year, and Cambodia which consumes $109 \mathrm{~kg}$ / capita / year. In addition, the consumption of vegetables should be increased to reduce high dependence on rice. The assassment of this lifeskill curriculum implementation was conducted in order to promote better consumption of vegetables for students through school vegetable garden models. School vegetable gardens in this activity is also designed to increase the availability of vegetables for family consumption. The gardens are arranged so that crops can be harvested almost every day and it is designed to use small land because most of families in Indonesia does not have a large homeyard. Students involved in the maintenance of vegetable crops as vegetable farming practice. Each harvest time, vegetables procued recapitulated and nutritional content calculated. In the future, Standard Operating Procedure (SOP) should be implemented in order to achieve the goals of the implementation of this curriculum and successful of the activities.
\end{abstract}

Key words: local content, lifeskills curriculum, consumption diversification, school vegetable garden 


\section{PENDAHULUAN}

Implementasi Muatan Lokal (Mulok) Kecakapan hidup (lifeskill) dalam pembelajaran di sekolah kini menjadi dimensi penting dalam proses pendidikan di Indonesia untuk menciptakan sumber daya manusia (SDM) pembangunan yang bermutu guna menjawab tantangan globalisasi yang keberadaannya tidak mungkin terhindarkan untuk tetap dapat bertahan dalam persaingan kehidupan di masa-masa mendatang (Hindun, 2005; Handayani, 2009). Kurikulum Mulok merupakan kegiatan kurikuler di sekolah yang bertujuan mengembangkan kompetensi siswa yang sesuai dengan ciri khas daerah, potensi daerah, kondisi lingkungan sosialekonomi masyarakat, termasuk keunggulan daerah yang dapat dikelompokkan kedalam mata pelajaran lain (Nasir, 2013). Mata pelajaran Mulok bertujuan memberikan bekal pengetahuan, keterampilan dan perilaku kepada peserta didik agar mereka memiliki wawasan yang mantap tentang lingkungan dan masyarakat sesuai dengan nilai yang berlaku di daerahnya dan mendukung kelangsungan pembangunan daerah serta pembangunan nasional secara umum (Yunus dan Budiharjo, 2009).

Pengembangan kurikulum yang mempersiapkan peserta didik untuk mengembangkan potensi daerah belum berjalan secara baik di masingmasing tingkat satuan pendidikan, hal ini ditandai dengan belum memasyarakatnya kurikulum Mulok yang mengembangkan potensi masing-masing daerah (Handayani, 2009). Pada umumnya, peserta didik yang terlibat dalam proses belajar akan berfikir tentang apa yang akan dikerjakan nantinya setelah menyelesaikan program pendidikan yang diikutinya. Artinya, setelah selesai mengikuti program pendidikan, peserta didik biasanya mengharapkan hasil yang kiranya dapatmemperbaiki kehidupannya. Oleh karena itu, pendidikan kecakapan hidup (life skill) harus lebih dominan dibandingkan dengan pendidikan akademik (Yunus dan Budiharjo, 2009).

Kegiatan pengenalan konsep lifeskill ini mendesain sebuah pembelajaran Mulok yang dapat membantu siswa memahami masalah yang ada di sekitarnya. Lebih jauh diharapkan siswa juga mampu memanfaatkan pelajaran tersebut untuk mendapatkan pengetahuan dan keterampilann untuk memecahkan masalah yang dihadapi dalam kehidupannya (Hindun, 2005). Bahkan pelajaran Mulok bisa jadi sebuah proses pelatihan keterampilan tertentu yang bisa membantu siswa untuk tumbuh kreatif dan inovatif sebagai modal untuk mendapatkan pekerjaan atau menciptakan lapangan kerja sendiri di masa yang akan datang.

Disisi lain, perlu dipahami oleh masyarakat kita bahwa Organisasi Kesehatan Dunia (WHO) PBB menyarankan agar konsumsi sayur dan buah setidaknya sebesar $400 \mathrm{~g} / \mathrm{hari}$ untuk mencegah penyakit (WHO, 2003). Konsumsi sayuran minimal yang diperlukan untuk diet seimbang ialah sebesar 200g/kapita/hari (Chadha et. al., 2011). Tingkat konsumsi sayur penduduk Indonesia masih di bawah standar kecukupan. Sebagai perbandingan, tingkat konsumsi sayur di Thailand ialah 300 $\mathrm{kg} / \mathrm{kapita} / \mathrm{tahun}$. Negara-negara yang tingkat konsumsi lebih tinggi dari Indonesia ialah Singapura, yang mengkonsumsi $120 \mathrm{~kg} / \mathrm{kapita} / \mathrm{tahun}$, kemudian 
Cina, mengkonsumsi $270 \mathrm{~kg} / \mathrm{kapita} / \mathrm{tahun}$, dan Kamboja yang mengkonsumsi 109 kg/kapita/tahun (Sekretaris Ditjen Hortikultura, 2010). Menurut Keatings, et. al., (2013) di ASIA bagian timur 87\% konsumsi sayur masyarakat mencapai 715 g/kapita/hari, ASIA bagian barat $56 \%$ konsumsi sayur mencapai $423 \mathrm{~g} / \mathrm{kapita/hari,} \mathrm{Central} \mathrm{ASIA}$ sebesar 59\% konsumsi sayur mencapai 423 g/kapita/hari, dan bagian ASIA selatan konsumsi sayur $71 \%$ mencapai $171 \mathrm{~g} / \mathrm{kapita} / \mathrm{hari}$.

\section{METODE PENELITIAN}

Kebun sayuran sekolah dalam kegiatan ini keluarga dirancang untuk meningkatkan ketersediaan sayuran bagi konsumsi keluarga. Itu sebabnya secara umum kebun tersebut dirancang menggunakan luas lahan yang kecil karena kebanyakan keluarga di Indonesia tidak memiliki halaman yang luas. Kebun sayuran sekolah dalam proyek yang didanai oleh USAID ini dilaksanakan di sekolah-sekolah untuk memperluas pengenalan rancangan kebun ke anakanak muda dengan harapan supaya ilmu tersebut dapat tersebar ke banyak keluarga. Adapun Standar Operasional Prosedur (SOP) dalam pelaksanaan kegiatan kebun sayur sekolah adalah sebagai berikut:

\section{a. Penentuan Jenis Tanaman dan Letak Kebun}

Memilih jenis sayuran yang akan ditanam memerlukan beberapa pertimbangan. Di bawah ini adalah contoh-contoh pertimbangan yang perlu dipikirkan sebelum menentukan jenis sayuran di kebun sekolah:

\begin{tabular}{|c|c|c|c|c|c|c|c|c|c|c|}
\hline & $\begin{array}{c}\text { Lahan } \\
1\end{array}$ & $\begin{array}{c}\text { Lahan } \\
2\end{array}$ & $\begin{array}{c}\text { Lahan } \\
3 \\
\end{array}$ & $\begin{array}{c}\text { Lahan } \\
4\end{array}$ & $\begin{array}{c}\text { Lahan } \\
5\end{array}$ & $\begin{array}{c}\text { Lahan } \\
6\end{array}$ & Lahan 7 & $\begin{array}{c}\text { Lahan } \\
8\end{array}$ & $\begin{array}{c}\text { Lahan } \\
9\end{array}$ & Lahan 10 \\
\hline Januari & \multirow{3}{*}{ Terong } & \multirow{3}{*}{ Okra } & \multirow{3}{*}{$\begin{array}{l}\text { Kacang } \\
\text { panjang }\end{array}$} & \multirow{3}{*}{ Ketimun } & \multirow{3}{*}{ Buncis } & \multirow{3}{*}{ Kangkung } & \multirow{3}{*}{ Cabe } & \multirow{3}{*}{ Pare } & Bayam & \multirow{3}{*}{ Tomat } \\
\hline Februari & & & & & & & & & & \\
\hline Maret & & & & & & & & & $\begin{array}{l}\text { daun } \\
\text { daun }\end{array}$ & \\
\hline Apri' & \multirow{3}{*}{$\begin{array}{l}\text { Kacang } \\
\text { parjiang }\end{array}$} & \multirow{3}{*}{$\begin{array}{l}\text { Bavang } \\
\text { merah }\end{array}$} & \multirow{3}{*}{ Cabe } & \multirow{3}{*}{$\begin{array}{l}\text { Bavang } \\
\text { putih }\end{array}$} & Bayam & \multirow{3}{*}{$\begin{array}{l}\text { Bavang } \\
\text { merah }\end{array}$} & \multirow{3}{*}{ Okra } & \multirow{3}{*}{ Tomat } & & \multirow{3}{*}{ Kangkung } \\
\hline Mei & & & & & & & & & & \\
\hline Juni & & & & & Kangkung & & & & Gambas & \\
\hline $\begin{array}{l}\text { Juli } \\
\text { Agustus }\end{array}$ & \multirow[t]{2}{*}{ Pare } & Kangkung & \multirow{2}{*}{$\begin{array}{l}\text { Bavang } \\
\text { merah }\end{array}$} & \multirow[t]{2}{*}{ Terong } & \multirow[t]{2}{*}{ Tomat } & \multirow[t]{2}{*}{ Cabe } & \multirow{2}{*}{$\begin{array}{l}\text { Bavang } \\
\text { merah }\end{array}$} & \multirow[t]{2}{*}{ Okra } & & \multirow[t]{2}{*}{$\begin{array}{l}\text { Bavang } \\
\text { pufh }\end{array}$} \\
\hline September & & Savi hjau & & & & & & & & \\
\hline Oktober & \multirow{2}{*}{ Kangkung } & \multirow{3}{*}{ Terong } & \multirow{3}{*}{ Tomat } & \multirow{3}{*}{ Waluh } & \multirow{3}{*}{ Pare } & \multirow{3}{*}{ Buncis } & \multirow{3}{*}{ Waluh } & \multirow{3}{*}{ Cabe } & Paprika & \multirow{3}{*}{ Ketimun } \\
\hline November & & & & & & & & & & \\
\hline Desember & Bayam & & & & & & & & $\begin{array}{l}\text { Savi } \\
\text { hiau }\end{array}$ & \\
\hline
\end{tabular}

\begin{tabular}{|c|c|c|c|c|c|c|c|c|c|c|c|c|}
\hline Plot no. & Jan & Feb & Mar & Apr & May & Jun & Jul & Aug & Sep & Oct & Nov & Dec \\
\hline 1 & $\infty$ & 0 & 0 & $4 \sqrt{2}$ & 4 & $\sqrt{2}$ & 8 & 8 & 8 & 1 & $\sqrt{1}$ & 需 \\
\hline 2 & $y$ & & $\Rightarrow$ & 2 & 2 & 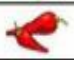 & 4 & 8 & 4 & 4 & 4 & $\sqrt{1}$ \\
\hline 3 & 0 & $\mathrm{O} \theta$ & 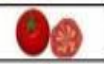 & 4 & 4 & 4 & 0 & 0 & 0 & 32 & $\angle$ & $\angle$ \\
\hline 4 & 4 & $\sqrt{1}$ & 4 & 8 & 8 & 8 & 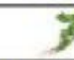 & & $\Rightarrow$ & 1 & 1 & 1 \\
\hline 5 & 8 & 8 & 8 & 0 & 20 & & 4 & 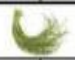 & $\mathrm{U}$ & 2 & 2 & $C$ \\
\hline 6 & $\angle 2$ & $\angle$ & 읗 & (1) & 8 & 4 & 흘 & & 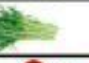 & 0 & 0 & 0 \\
\hline 7 & 2 & 2 & 2 & 3 & 89 & 5 & & & 20 & 3 & 8 & 8 \\
\hline 8 & 7 & 采 & $y$ & 题 & 䨔 & 2 & $C$ & $C$ & $\underline{L}$ & $\angle$ & N & * \\
\hline 9 & 卷 & 卷 & * & * & 桊 & 荻 & * & 类" & 卷 & 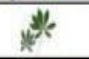 & 卷 & "* \\
\hline 10 & 징 & & 糸 & 0 & 0 & 0 & $\sqrt{a}$ & $\sqrt{2}$ & $\sqrt{1}$ & $\Rightarrow$ & & 3 \\
\hline
\end{tabular}

Rainy season $\square$ Dry season 
- Selera masyarakat lokal

- Adaptasi terhadap suhu, ketinggian, musim dan sifat-sifat agro-ekologi setempat

- Kandungan nutrisi untuk memperbaiki nilai gizi makanan yang dikonsumsi penduduk setempat

- Sayuran tradisional (bayam, daun ubi jalar, kangkung, dsb.) dan sayuran global (tomat, cabe, kubis, dsb.)

- Keinginan untuk mencoba bertanam jenis atau varietas sayuran yang baru

Berdasarkan pertimbangan yang didiskusikan dengan masyarakat setempat, jenis sayuran di bawah ini dipilih untuk pilot kebun sekolah tahun pertama sebaiknya adalah tanaman yang cepat tumbuh, tahan terhadap serangan Organisme Pengganggu Tanaman (OPT) dan disukaimsyarakat sperti Terong, okra, kacang panjang, ketimun, buncis, kangkung, sawi hijau, cabe, pare, bawang daun, tomat, bawang merah, bawang putih, bayam, gambas, waluh dan paprika.

Untuk menentukan letak kebun, pilihlah lahan yang disinari matahari sepanjang hari dan tidak ternaungi. Jika mungkin, pilihlah lahan yang tanahnya subur dan pengaliran air (drainase) baik. Jika tanahnya tidak subur, dapat diperbaiki dengan pemupukan atau penambahan bahan-bahan untuk memperbaiki sifat tanah (misalnya kompos, kapur, dsb).

\section{b. Tata letak kebun}

Ukuran kebun sekolah adalah $6 \mathrm{~m}$ x $6 \mathrm{~m}$ yang dibagi menjadi 5 lahan berukuran $6 \mathrm{~m} \times 1 \mathrm{~m}$. Meskipun tata letak kebun dapat dibuat secara fleksibel, jumlah luas lahan sebaiknya dibuat berbanding dengan $6 \mathrm{~m} \times 6 \mathrm{~m}$. Jika sekolah/keluarga tidak memiliki lahan seluas $36 \mathrm{~m}^{2}$ di satu tempat, letak kebun dapat di rancang di beberapa tempat. Misalnya 2 lahan berukuran $6 \times 1 \mathrm{~m}^{2}$ terletak di belakang sekolah sedangkan 3 lahan berikutnya terletak di samping gedung sekolah.

\section{c. Persiapan lahan}

Lima lahan berukuran $1 \mathrm{~m}$ x $6 \mathrm{~m}$ dibentuk dan diolah dengan saluran pengairan berukuran 25 cm di antara dua lahan. Satu lahan dapat ditanami 2 atau 3 jenis sayuran, sehingga dibagi menjadi 2 atau 3 sub-lahan berukuran $1 \mathrm{~m}$ x $3 \mathrm{~m}$. Buatlah tanggul/pematang mengelilingi kebun sehingga pengairan tidak melimpah ke luar areal kebun. Lahan dibajak dua atau tiga kali dan pupuk kandang di campurkan ke dalam tanah. Bahan-bahan perbaikan sifat tanah juga dapat ditambahkan seperlunya.

\section{d. Kalender Tanam/Pola Tanam}

Jenis-jenis sayuran yang terpilih ditanam kedalam 10 sub-lahan menurut urutan yang disesuaikan dengan musim tanam. Untuk pilot percobaan, jadwal tanam selama satu tahun telah di rencanakan untuk Jawa Timur di bawah ini. Lahan pilot percobaan diperlukan untuk menguji kelayakan urutan pola tanam tersebut (Gambar 1).

\section{e. Benih untuk kebun sekolah}

Untuk penanaman tahun pertama, benih sayuran dapat dibeli dari distributor benih setempat, didapat dari institutisi pertanian nasional atau dari proyek pertanian. Varietas hibrida (F1) atau penyerbukan (polinasi) terbuka dapat digunakan. Untuk musim tanam selanjutnya, benih dari varietas 
polinasi terbuka dari kebun sekolah dapat disimpan untuk musim-musim tanam selanjutnya. Catatlah dari mana asal/sumber benih dan semua varietas yang ditanam di kebun sekolah.

\section{f. Penanaman dan cara persiapan benih/bibit}

- Pakailah baki plastik yang memiliki 50 lubang untuk penanaman biji (lubang berukuran dalam 4 $\mathrm{cm}$ dan diameter $4.6 \mathrm{~cm}$ ). Jika baki plastik untuk penanaman biji tidak tersedia, biji dapat ditanam di wadah-wadah yang mirip. Misalnya, contong yang dibuat dari daun pisang atau wadah sisa es krim dsb.

- Pakailah campuran tanah untuk pot yang berisi kompos:sekam padi:pasir dengan perbandingan 3:1:1. Paling baik jika campuran tanah tersebut dijaga cukup bersih. Jika memungkinan, campuran tanah dapat di sterilisasi.

- Tanamlah satu atau dua biji ke dalam satu lubang. Letakkan plastik di atas bangku yang dilindungi dengan jaring nilon berukuran 50-mesh.

- Biji disiram air setiap hari (lebih baik dilakukan di pagi hari), tergantung suhu dan kelembaban udara. Berilah larutan NPK (19:19:19) dua kali berjarak 15 hari. Setiap benih diberi $5 \mathrm{ml}$ larutan NPK sebelum dipindah ke lahan.

- Benih yang tumbuh dengan baik dipilih untuk dipindahkan ke lahan.

- Catatlah tanggal penanaman biji dan tanggal pada waktu memindahkan benih ke lahan

\section{g. Pengelolaan tanaman}

- Tanaman dikelola sesuai dengan cara-cara pengelolaan setempat. Hindarilah pemakaian pestisida yang berlebihan. Karena kebun sekolah ini tidak terlalu luas, pengendalian hama secara manual (dengan tangan) masih memungkinkan untuk dilakukan.

- Catatlah cara-cara pengelolaan di bawah ini:

- Jarak tanam, jumlah tanaman per lahan

- Keadaaan pertumbuhan tanaman

- Serangan hama dan penyakit

- Bahan-bahan kimia yang dipakai (untuk perbaikan sifat tanah, pupuk, pestisida, dsb.)

- Bahan/metode lain yang dipakai untuk mengendalikan hama dan penyakit.

\section{h. Panen}

- Setelah tanaman siap dipanen, panenlah 1-3 kali per minggu sesuai dengan jenis tanaman dan tahap kematangannya. Catatlah tanggal pemanenan.

- Setiap kali panen, bagian tanaman yang dapat dikonsumsi (misalnya buah terong atau daun bayam) ditimbang dan beratnya dicatat.

- Catatlah rencana untuk penggunaan hasil panen. Misalnya, apakah hasil panen akan dibagi diantara murid-murid yang mengelola kebun sekolah? Atau akan dijual ke guru-guru dan orang-tua murid? Atau akan disumbangkan ke panti asuhan atau diberikan ke keluarga miskin?

\section{i. Menyimpan biji penyerbukan terbuka}

Untuk jenis sayuran yang berbuah (misalnya terong, cabe, tomat), piliahlah 5 tanaman yang sehat dan tumbuh dengan baik. Dari tanamantanaman tersebut, biarkan (jangan dipanen) 5-10 buah yang bebas serangan hama/penyakit. Biji dari buah tersebut dapat disimpan untuk musim tanam berikutnya. Untuk jenis sayuran daun (misalnya 
kangkung dan bayam), pilihlah 5 tanaman sehat dan tumbuh dengan baik. Tanaman-tanaman tersebut jangan dipanen, biarkan tumbuh di lahan sampai bijinya matang dan siap dipanen.

\section{j. Dokumentasi dan Pencatatan}

Ambillah foto kebun sekolah sebelum dan sesudah mempersiapkan lahan. Foto-foto juga perlu diambil dari berbagai tahap pertumbuhan tanaman di lahan - misalnya, benih sebelum dipindah ke lahan, benih setelah dipindah ke lahan berumur 2-4 minggu, serangan hama dan penyakit, tahap berbunga, tahap berbuah, panen, sayuran setelah dimasak, dsb. Usahakan untuk mengambil foto sebanyak mungkin dan jangan lupa setiap foto diberi catatan yang cukup rinci/detil. Kegiatankegiatan lain yang dilakukan di lahan sehubungan dengan kebun sekolah juga perlu dicatat

\section{k. Evaluasi Kegiatan dan respons Sekolah}

Setiap akhir musim atau akhir semester kegiatan sekolah, lakukanlah evaluasi dari kegiatan ini secara bersama antara siswa dan guru pembimbing untuk mendapatkan masukkan mengenai berbagai kendala selama pelaksanaan kegiatan, respon dari para siswa pelaksana, rencana pengembangan kedepan dan lain sebagainya. Satu hal yang tidak kalah penting adalah mendapatkan informasi mengenai respon dari keluarga atau teman di luar sekolah mengenai kegiatan budidaya sayuran di sesekolah yang telah mereka lakukan.

\section{HASIL DAN PEMBAHASAN}

Pentingnya Pengenalan Konsep Kebun Sekolah (School Garden)
Kementrian Pertanian menyatakan bahwa konsumsi buah dan sayur di Indonesia masih di bawah standar yang ditetapkan Organisasi Pangan dan Pertanian (FAO). Konsumsi sayur di Indonesia pada tahun 2005 ialah $35,30 \mathrm{~kg} / \mathrm{kapita} /$ tahun, sedangkan tahun 2006 mencapai 34.06 kg/kapita/tahun (Agroprima, 2010). Pada tahun 2008, angka ini meningkat menjadi 39,45 $\mathrm{kg} /$ kapita/tahun. Di sisi lain, produksi sayuran Indonesia juga menunjukkan peningkatan sebesar 1,89\% selama periode 2008-2009 (Sekretaris Ditjen Hortikultura, 2010). Berdasarkan hasil kajian Badan Litbang Pertanian, Kementerian Pertanian Maret 2013, tingkat konsumsi buah per kapita hanya 34,55 $\mathrm{kg} /$ tahun, sedangkan tingkat konsumsi sayuran per kapita 40,35 kg/tahun. Sebagai perbandingan, konsumsi buah dan sayur per kapita bagi warga Singapura dan Vietnam melebihi 100 kg/tahun (Abdurrahman, 2013).

Kebun Sekolah (School Garden), bertujuan untuk memperluas pengenalan model kebun keluarga kepada siswa. Dalam studi ini dilakukan pengenalan konsep kebun sayur sekolah juga dimaksudkan untuk meningkatkan pengetahuan tentang sayuran, termasuk nantinya siswa akan terbiasa mengkonsumsi berbagai jenis sayuran. Budidaya sayuran di sekolah sangat bermanfaat untuk mengenalkan jenis sayuran baru, meningkatkan minat siswa untuk mengkonsumsi sayuran, dan mengurangi pengeluaran untuk membeli makanan bergizi. Kebun sayur ini dirancang di lahan sempit, karena di Indonesia sebagian besar keluarga tidak memiliki area pekarangan yang luas. Pendekatan 
untuk mengatasi masalah kekurangan gizi membutuhkan jumlah protein yang cukup, karbohidrat serta mikronutrien yang memadai di dalam bahan pangan (Ali and Tsou, 1997). Seperti yang terjadi di Afrika tekanan pertumbuhan penduduk dan kemiskinan dapat menimbulkan gizi buruk dan diproyeksikan akan terus terjadi sampai dengan tahun 2020 (IFPRI, 2001).

Oleh sebab itu Stephenson et. al., (2000) menyatakan bahwa kebun sayur sekolah dapat mengatasi kekurangan gizi yang sering dialami para siswa sekolah. Hasil penelitian AVRDC (Asian Vegetable Research and Development Center) antara tahun 1990 sampai dengan tahun 2000 bahwa penerapan program kebun sayur dengan responden sebanyak 30.000 rumah tangga di Bangladesh, Kamboja, Nepal dan Filipina dapat meningkatkan konsumsi sayuran secara signifikan. Penerapan kebun sayur ini juga dapat meningkatkan pendapatan rumah tangga di berbagai negara tersebut. Namun peningkatan bervariasi diantara negara-negara tersebut. Kamboja merupakan negara dengan peningkatan pendapatan yang terbesar. Di samping itu kebun sayur di Bangladesh secara nyata juga menurunkan prevalensi penyakit anemia (Bushamuka et. al., 2005)

Untuk memenuhi kebutuhan sayur sehari-hari, sebuah rumah tangga dapat memiliki kebun sayur keluarga di pekarangan yang tidak perlu luas. Jika tidak memiliki lahan, masyarakat dapat menggunakan pot kecil atau polibag. Ada beberapa alasan untuk menanam sayuran di halaman, yaitu memenuhi kebutuhan sayur, hobi, bebas bahan kimiawi, karena dapat menekan penggunaan pestisida dan melatih seluruh anggota keluarga untuk dapat mencintai alam (Abdoellah, et.al., 2001; Mariyono dan Bhattarai, 2010). Ada beberapa jenis sayuran dapat ditanam di kebun sekolah, yaitu (a) sayuran buah besar seperti paprika, cabe rawit, kacang polong, kecipir, tomat, buncis, kacang panjang, terong, mentimun, pare dan merica; (b) sayuran berdaun sepertis sawi, daun bawang, bayam, kubis, kemangi, seledri, selada, dan daun talas (c) sayuran bunga seperti kol, brokoli dan bunga pepaya, (d) akar sayuran seperti wortel, kentang, bawang, bawang putih, lobak, herbal dan tanaman obat seperti kunci, serai, kunyit tanah masih termasuk umbi sayuran (Mir, 2011; Sharrock dan Frison, 2004, Mariyono, et. al., 2010).

Proyek Asean Vegetable Research Development Centre (AVRDC) di beberapa negara di Asia Pasifik menyimpulkan bahwa lahan seluas $36 \mathrm{~m}^{2}$ yang ditanami sayuran dapat menyediakan konsumsi ratarata sebesar $750 \mathrm{gr} /$ hari sayuran sepanjang tahun (Gambar 2). Jika produksi sayur tersebut dibagikan kepada keluarga yang masing-masing berisi empat orang anggota, maka masing-masing orang akan

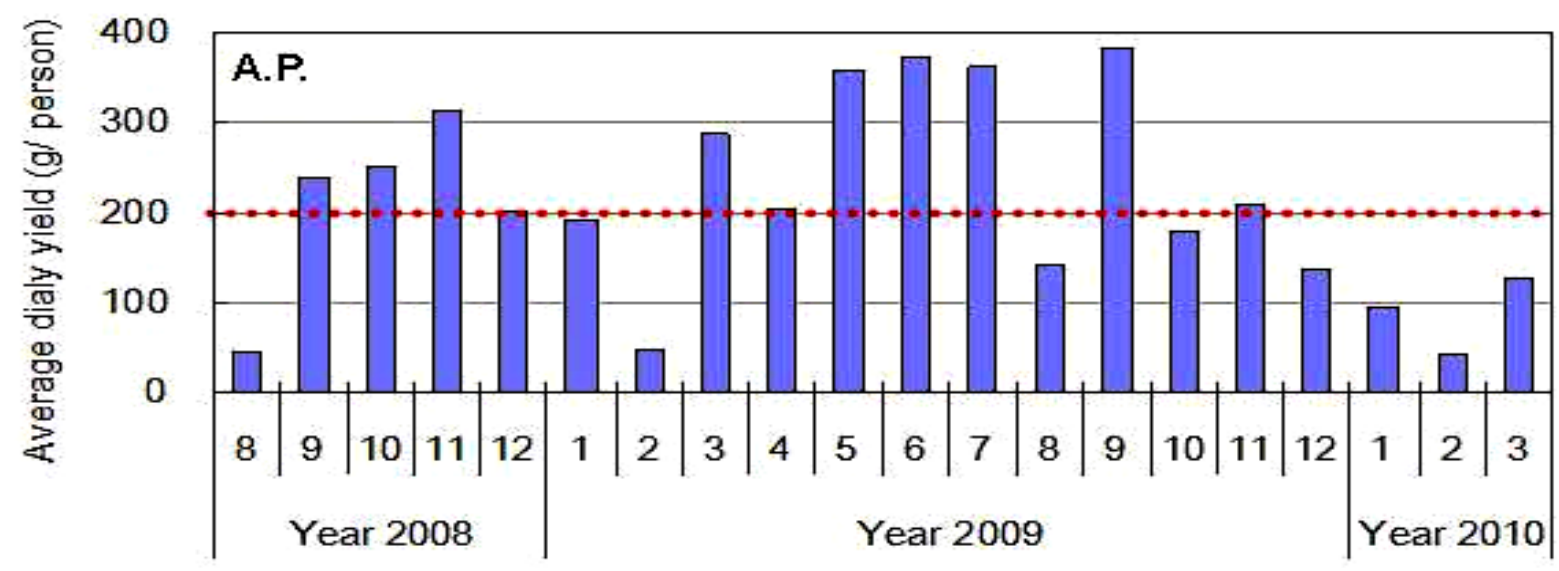

Gambar 2. Rata-rata panen harian sayur dari Kebun Sayuran di Asia Pasifik dengan luas $6 \mathrm{~m} \times 6 \mathrm{~m}^{2}$ (Sumber: Chadha, et.al. 2010) 
mengkonsumsi sayuran 187g/kapita/hari, yang artinya sudah mendekati rekomendasi FAO (Chadha, et. al., 2010). Hasil penelitian di dua propinsi India menyimpulkan bahwa keluarga yang memiliki kebun sayur seluas $36 \mathrm{~m}^{2}$ (6mx6m) mampu menyediakan asupan sayuran seperti yang direkomendasikan FAO. Hasil analisis nutrisi juga menunjukkan bahwa kebun sayur keluarga dapat menyediakan lebih dari $100 \%$ vitamin $\mathrm{A}$ dan $\mathrm{C}$ untuk kehidupan sehari-hari, serta zat besi tambahan dan protein (Keatinge, et. al., 2011).

\section{Implementasi Mulok (Muatan Lokal) Kebun Sayur Sekolah Oleh BPTP JATIM}

Rendahnya minat generasi muda terutama anak-anak pada dunia pertanian merupakan hal yang ironis mengingat Indonesia merupakan salah satu negara agraris besar di dunia. BPTP (Balai Pengkajian Teknologi Pertanian) Jawa Timur sebagai salah satu UPT Kementerian Pertanian berusaha mengembalikan citra pertanian dengan mengembangkan kegiatan outbond di lokasi BPTP. Salah satunya menjalin kerjasama dengan AVRDC dengan mengembangkan Kebun Sayur Sekolah.

Kebun Sayur Sekolah yang merupakan salah satu kegiatan yang dikembangkan oleh AVRDC (Asean Vegetable Research Development Centre) mencoba menjembatani keinginan tersebut dengan membudidayakan beberapa tanaman sayuran lokal seperti kangkung dan bayam dan sayuran global seperti cabai dan tomat. Garden School merupakan wadah pembelajaran bagi anak-anak usia didik (PAUD, TK, SD, SMP dan SMA) untuk mangenal tanaman sayuran secara lebih dekat tidak hanya buah atau daunnya yang biasa digunakan sebagai sayuran tetapi juga cara budidaya, bentuk tanaman selama masih di lahan dll. Pada tahap awal kegiatan ini

Pengkajian Kebun Sayur Sekolah selama periode tahun 2011 sampai dengan tahun 2014 telah dilakukan di 15 sekolah di Jawa Timur dari jenjang pendidikan usia dini sampai dengan SMA. Kegiatan dilakukan dalam periode tahun 2011 sampai dengan 2014 yang merupakan kegiatan kerjasama antara Balai Pengkajian Teknologi Pertanian (BPTP Jawa Timur) dengan AVRDC (Asian Vegetable Research and Development Center) dan didanai penuh oleh USAID. Pada tahun 2011-2012 terdapat 6 sekolah yang menerapkan pendidikan lifeskill kebun sayur sekolah yaitu : SMK Negeri Plosoklaten II, SMPN Plemahan II Kediri, SDN Pohjarak I Kediri, TK Al Hidayah Blitar, SDN Plosorejo I Blitar dan SDN Plosorejo III Blitar. Sedangkan di tahun 2013-2014 terdapat 9 sekolah yang melaksanakan pendidikan lifeskill School Garden yaitu : SMA Negeri 7 Malang, SMA Negeri 2 Kediri, SMP Negeri 10 Probolinggo, SMP Negeri 4 Mojokerto, SMP Negeri 6 Mojokerto, SMP Negeri 3 Ngimbang Lamongan, SMK NU Al-Hidayah Ngimbang Lamongan, SMK Negri 2 Kediri dan SMK NU Al-Hidayah Blitar.

Kebun Sayur Sekolah secara umum bertujuan mempromosikan peningkatan konsumsi sayuran siswa melalui pengenalan model kebun sayur sekolah. Sedangkan secara khusus kegiatan ini bertujuan meningkatkan pengetahuan dan minat anak-anak sekolah terhadap kegiatan pertanian khususnya komoditas sayuran dan untuk 
pemanfaatan sumberdaya alam sekitar. Siswa mengetahui bermacam-macam manfaat sayuran dan cara budidaya/pemeliharaannya.

Dengan bertambahnya pengetahuan siswa, diharapkan mereka dapat menerapkan konsep kebun sayur dan pemanfaatan sumberdaya lokal di lingkungannya. Selanjutnya diharapkan siswa dapat menerapkan konsep tersebut di keluarga masingmasing.

Sosialisasi model kebun sayur dimulai sebelum tanam. Siswa diperkenalkan dengan berbagai jenis sayur yang akan ditanam. Berikutnya siswa juga diberi penjelasan cara bercocok tanam sayuran, cara ploting lahan, serta pengendalian hama dan penyakit. Setelah sayuran ditanam, selain merawat pertumbuhan, siswa juga diajarkan cara membuat pupuk kandang dan membibitkan sayuran.

Dengan demikian, diharapkan siswa mampu mempengaruhi orang tuanya agar bertanam sayur di rumah masing-masing. Partisipasi siswa bukan hanya dalam budidaya akan tetapi juga dalam kegiatan pengamatan pertumbuhan tanaman sampai dengan panen. Kegiatan panen dilakukan untuk setiap macam komoditas sayuran 1-3 kali per minggu pada tanaman yang siap panen, kemudian dilakukan penimbangan dan pencatatan.

Cakupan kegiatan selama implementasi pelaksanaan pendidikan Mulok (Mulok) Kecakapan Hidup (Lifeskill) berbasis pertanian melalui Kebun Sayuran Sekolah ini meliputi : (a) koordinasi dengan dinas terkait (b) koordinasi dengan pemerintah lokal (c) Pra studi mengenai potensi local dan pengembangan wilayah di daerah ini (d) Sosialisasi mengenai muatan local yang akan dilaksanakan kepada sekolah-sekolah tersebut (e) Survey awal untuk mengetahui pengetahuan guru dan siswa tentang potensi alam, kegiatan budidaya sayuran dan pemanfaatan lahan, perikanan, peternakan dan potensi pengolahan perikanan (f) TOT kegiatan muatan local ini kepada guru dan pembimbing, (g) Pemberian materi pembelajaran yang terkait dengan muatan local kepada siswa (g) praktek dan pelaksanaan kegiatan muatan local di kurikulum sekolah dan (h) monitoring dan evaluasi akhir dari pelaksanaan muatan local ini sekolah-sekolah tersebut.

\section{KESIMPULAN}

Tingkat konsumsi sayur penduduk Indonesia masih di bawah standar kecukupan. Kebun Sayur Sekolah melalui Mulok lifeskill bertujuan untuk memperluas pengenalan model kebun keluarga kepada siswa. Dalam kegiatan ini dilakukan pengenalan konsep kebun sayur sekolah juga dimaksudkan untuk meningkatkan pengetahuan tentang aspek budidaya sayuran, termasuk nantinya siswa akan terbiasa mengkonsumsi berbagai jenis sayuran.

Perlu penerapan Standar Operasional Presedur pelaksanaan kegiatan ini agar dapat berhasil dan mencapai tujuan dari pelaksanaan kurikulum ini. Di dalam penerapan kebun sayur sekolah perlu pengaturan pola tanam sayuran yang disesuaikan dengan keseimbangan nutrisi yang direkomendasi, sehingga diperoleh hasil panen 
sayur yang mempunyai komposisi kandungan gizi yang seimbang.

\section{UCAPAN TERIMA KASIH}

Ucapan terima kasih kami sampaikan kepada ibu Kartini Luther yang memberikan ide serta masukan pada pembuatan makalah. Ucapan terima kasih juga kami sampaikan kepada AVRDC - The World Vegetable Centre dan USAID yang mendanai kegiatan penelitian ini oleh BPTP Jawa Timur.

\section{DAFTAR PUSTAKA}

Abdoellah, Oekan S., Parikesit, Budhi Gunawan and Herri Y. Hadikusumah. 2001. Home gardens in the Upper Citarum Watershed, West Java: a challenge for in situ conservation of plant genetic resources. Paper Presented at International Workshop: Contribution of home gardens to in situ conservation of plant genetic resources in farming systems. 17-19 July , 2001, Witzenhausen, Germany.

Abdurrahman.M.Nur. 2013. Konsumsi buah dan sayur di Indonesia ketinggalan dari negara tetangga.http://health.detik.com/read/2013/06/28/ 190119/2287595/763/konsumsi-buah-dan-sayurdi-indonesia-ketinggalan-dari-negara-tetangga diakses 10/9/2013 pkl.10.03.

Agromedia, Pustaka. 2005. Menanam Sayuran di Pekarangan Rumah. Penerbit Agromedia Pustaka.

Ali M, tsou CS. 1997. Combating micronutrient deficiences through vegetables. a neglected food frontier in Asia. Food Policy. 22: 17-38.

Bushamuka VN, de Pee S, Talukder A, Kiess L, Panagides D, Abu Taher, Bloem M, 2005. Impact of a homestead gardening program on household food security and empowerment of women in Bangladesh. United Nations University Food Nutr. Bull.26 :17-25.

Chadha, M.L. Ray-yu Yang, Satish K. Sain, C. Triveni, Roohani Pal, M. Ravishankar and T.R.
Ghai. 2010. Home gardens: an intervention for improved health and nutrition in selected states of India. Procceding of $28^{\text {th }}$ International Horticultural Congress.Lisboa, August 22-27, 2010.

Chadha, M.L. Ray-Yu Yang, Satish K. Sain, C. Triveni, Roohani Pal, M. Ravishankar and T.R. Ghai. 2010. Home gardens: an intervention for improved health and nutrition in selected states of India. Proceedings of $28^{\text {th }}$ International Horticultural Congress. Lisboa, August 22-27, 2010.

Handayani, Sri, 2009. Muatan Life Skills Dalam Pembelajaran Di Sekolah: Upaya Menciptakan Sumber Daya Manusia Yang Bermutu. Prosiding Konferensi Internasional Pendidikan, UPI UPSI, Malaysia.

Hindun, Iin, 2005. Model Pengembangan Pendidikan Kecakapan Hidup (Life Skill) pada Sekolah Umum Tingkat Menengah di Kota Batu. Humanity, Vol. 1 No. 1 September 2005: 29-35.

IFPRI.2001. Empowering women to achieve food security. Vision 2020. Focus No.6 washington DC, International Food Policy Research Institute.

J.D.H. Keatings, R J Holmer, A.W Ebert and J.A. Hughes. 2010. Less Visible but Yet Vital for Human Health Nutrient Dense Indigenous Vegetables and Their Need for Urgent Promotion in Balanced Diets. AVRDC.

Keatinge JDH, Yang R-Y, Hughes J d'A, Easdown WJ, Holmer R.2011. The Importance of ensuring both food and nutritional security in attainment of the Millennium Development Goals.Food Sec.3:491-501.

Khaw,K, Bingham,S, Welch, A, Luben, R, Wareham, N, Oakes, S \& Day, N. 2001. Relation between plasma ascorbic acid and mortality in men and women in EPIC- Norfolk prospective study: a prospective population study. The Lancet, 357:657-663.

Mariyono, J. Dibiyantoro, A., Bhattarai, M. 2010. Improved technologies in vegetable production to support food safety and food security: A case of chili farming in Central Java. Paper presentation of the International Conference on Food Safety 
and Food Security, 1st-4th December 2010, Universitas Gadjah Mada, Yogyakarta, Indonesia.

Mariyono, J. and Bhattarai, M. 2010. Revitalizing Indonesian rural economy through intensive farming of high value vegetables. The 10th IRSA International Conference., Surabaya, 28-29 July 2010.

Mir, Laura Calvet. 2011. Beyond food production: Ecosystem services provided by home gardens. A case study in Vall Fosca, Catalan Pyrenees, northeastern Spain", A PhD Thesis, Institut de Ciència i Tecnologia Ambientals Universitat Autònoma de Barcelona.

Nasir, Muhammad, 2013. Pengembangan Kurikulum Muatan Lokal Dalam Konteks Pendidikan Islam Di Madrasah. Hunafa: Jurnal Studia Islamika. Vol. 10, No. 1, Juni 2013: 1-18

Sekretariat Dirjen (Sekdirjen) Hortikultura. 2010. Produksi Tanaman Sayuran di Indonesia Periode 2007-2009.
Sharrock, S.L., and E.A Frison. 2004. Prospect and challenge of biodiversity in small-holder systems. African Crop Science Journal, Vol. 12, No. 1, pp. 51-57, 2004, Uganda.

Stephenson LS, Latham MC, Ottesen EA.2000.Malnutrition and Parasitic HelmintInfections. Parasitol.121:S23-S38.

World Health Organization (WHO). 2003. Initiative to Promote fruit and vegetables for Health Worldwide.

http://www.who.int/dietphysicalactivity/fruit/en /index.html diakses 16/1/2013 pkl.14.00

Yunus dan Budiharjo, 2009, Pengembangan Model Kurikulum Tingkat Satuan Pendidikan (KTSP) Pendidikan Kecakapan Hidup (Life Skill Education) Pada Sekolah Menengah Kejuruan (SMK) : Laporan Penelitian. Lembaga Penelitian Universitas Negeri Surabaya 